\title{
Sistem Pendukung Keputusan Penentuan Kualitas Benih Bunga Viola Menggunakan Simple Additive Weighting
}

\author{
Nina Setiyawati*, Elya Eko Widiyanto \\ Teknik Informatika, Fakultas Teknologi Informasi, Universitas Kristen Satya Wacana, \\ Jl. Diponegoro No.52-60, Salatiga, Kec. Sidorejo, Kota Salatiga, Jawa Tengah 50711 \\ *e-mail:nina.setiyawati@uksw.edu
}

(received: 20 April 2021, revised: 16 Juni 2021, accepted: 23 Juli 2021)

\begin{abstract}
Abstrak
Bidang pertanian di Indonesia saat ini semakin berkembang pesat. Salah satunya adalah komoditas bunga yang telah berhasil diekspor hingga ke banyak negara. Banyak kriteria yang ditentukan untuk memenuhi standar ekspor. Bunga Viola merupakan salah satu komoditas ekspor Indonesia, di mana kualitas benih bunga sangat diperhatikan untuk menjaga permintaan pasar internasional. Oleh karena itu, bunga Viola harus melalui tahap penentuan kualitas dan pemeringkatan sebelum dikirim. Sayangnya proses pendataan yang dilakukan secara manual menyebabkan ketidak akuratan data. Proses pemeringkatan yang dibutuhkan cukup panjang dan hal tersebut rentan dengan kehilangan berkas manual maupun pencatatan yang tidak akurat sehingga memperlambat proses penentuan ranking. Penelitian ini bertujuan untuk mengimplementasikan metode Simple Additive Weighting (SAW) untuk menentukan kualitas benih bunga Viola. Aplikasi dibangun menggunakan bahasa pemrograma Hypertext Prepocessor (PHP), framework CSS Bootstrap, serta database MySQL. Dari hasil pengujian didapatkan bahwa metode SAW mampu menentukan kualitas benih bunga Viola dengan akurasi 83,34\% dan presisi pada kualitas Baik adalah 92,1\%.
\end{abstract}

Kata kunci: kualitas benih, ranking benih, simple additive weighting

\section{Abstract}

The agricultural sector in Indonesia is currently growing rapidly. One of them is flower commodities which have been successfully exported to many countries. Many criteria are specified to meet export standards. Viola flower is one of Indonesia's export commodities, where the quality of flower seeds is very important to maintain international market demand. Therefore, Viola flowers must go through a quality determination and rating stage before being sent. Unfortunately the data collection process that is done manually causes data inaccuracies. The ranking process required is quite long and it is vulnerable to loss of manual files or inaccurate records, thus slowing down the ranking process. This study aims to implement the Simple Additive Weighting (SAW) method to determine the quality of Viola flower seeds. The application is built using the Hypertext Preprocessor (PHP) programming language, CSS Bootstrap framework, and MySQL database. From the test results, it was found that the SAW method was able to determine the quality of Viola flower seeds with an accuracy of $83.34 \%$ and the precision on Good quality was $92.1 \%$.

Keywords: seed ranking, seed quality, simple additive weighting

\section{Pendahuluan}

PT. Selektani adalah perusahaan yang bergerak dalam bidang pertanian yang menawarkan berbagai jenis benih bunga dan benih sayuran berkualitas di berbagai negara di Eropa dan beberapa perusahaan di Indonesia. Salah satu komoditas unggulan PT. Selektani adalah biji bunga Viola. Hal ini dikarenakan biji bunga Viola memiliki keunggulan kandungan senyawa aktif yang baik untuk kesehatan. Dalam hasil wawancara yang dilakukan dengan PT. Selektani cabang Ngablak data menunjukkan bahwa pada tahun 2016 rata-rata Belanda mengimpor benih bunga Viola $427 \mathrm{~kg} / \mathrm{bulan}$, Jerman $40 \mathrm{~kg} / \mathrm{bulan}$ dan Polandia $17 \mathrm{~kg} / \mathrm{bulan}$. Dalam satu gram biji bunga Viola berisi 1000 butir benih biji bunga. Bunga Viola memiliki keunikan diantaranya ukuran bunga yang hanya 20 inci, tidak memiliki batang bunga, daun memiliki warna dan daun yang berbentuk hati. 
Untuk mendapatkan biji bunga Viola yang berkualitas, PT. Selektani mempunyai prosedur, yaitu dengan menetapkan beberapa kriteria induk bunga yang menghasilkan biji bunga Viola. Adapun kriteria tersebut adalah tinggi tanaman, jumlah daun, jumlah bunga, dan produktifitas atau banyaknya produksi bunga, di mana pekerja akan melihat dan mengukur tanaman bunga Viola berdasarkan kriteria tersebut pada setiap waktu yang telah ditetapkan untuk menentukan ranking bunga Viola. Permasalahan yang terjadi pada proses penentuan ranking tersebut adalah pemeringkatan yang lama, rentan akan ketidak akuratan ranking yang dihasilkan, serta rentan kehilangan berkas. Melihat dari segi bisnis, lambatnya penentuan ranking kualitas biji bunga atau tidak akuratnya ranking yang dihasilkan akan berdampak pada beberapa aktivitas di perusahaan serta permintaan pasar yang bisa menurun. Adapun salah satu upaya yang dapat dilakukan dalam meningkatkan jumlah dan kualitas produksi pertanian serta mendukung efisiensi dan efektifitas dalam kegiatan pertanian, adalah dengan memanfaatkan teknologi informasi dan komunikasi [1]-[3].

Penelitian ini bertujuan untuk membangun Sistem Pendukung Keputusan Penentuan Kualitas Benih Bunga Viola dengan mengimplementasikan Fuzzy Multiple Attribute Decision Making (FADM) menggunakan metode Simple Additive Weighting (SAW) [4] untuk menentukan ranking kualitas biji bunga. FADM dipilih karena dapat menentukan nilai bobot untuk setiap atribut [5] dan metode SAW membantu dalam menyeleksi alternatif terbaik dari sejumlah alternatif berdasarkan kriteria-kriteria yang ditentukan dengan melakukan perangkingan untuk mengetahui nilai tertinggi hingga terendah. Aplikasi dibangun menggunakan bahasa pemrograman Hypertext Preprocessor (PHP), framework Cascading Style Sheet (CSS) Bootstrap, serta database MySQL yang bermanfaat untuk mengelola data dan menyeleksi data yang diambil sesuai dengan protokol yang diperlukan.

\section{Tinjauan Literatur}

Terdapat beberapa penelitian terdahulu yang menjadi acuan dalam penelitian ini, salah satunya adalah penelitian yang berjudul "Sistem Pendukung Keputusan Penerimaan Karyawan Menggunakan Simple Additive Weighting Studi Kasus PT. Trafoindo Prima Perkasa". Pada penelitian tersebut dijelaskan bahwa terdapat kesulitan menentukan calon karyawan pada jabatan tertentu dikarenakan penyeleksian dilakukan secara subjektif sehingga dalam penilaian sering terjadi calon karyawan kurang mampu bekerja secara optimal dan tidak dapat bertahan lama dalam organisasi. Hasil dari penelitian menggunakan logika fuzzy dengan metode SAW tersebut adalah dapat membandingkan penilaian calon karyawan yang akurat sehingga dapat mendapat calon karyawan yang sesuai dengan yang perusahaan butuhkan [6].

Penelitian lainya adalah "Perancangan Aplikasi Android Hybrid Untuk Pemilihan Lokasi Kuliner". Pada penelitian tersebut terdapat permasalahan perbedaan harga pada rumah makan, hal ini mendorong untuk mendapatkan informasi rumah makan tersebut. Pada proses perancangan sistem informasi tersebut dijelaskan menggunakan metode Simple Additive Weighting (SAW). Hasil dari perancangan tersebut adalah dapat menampilkan opsi rumah makan terbaik melalui visualisasi peta dari Google Maps yang juga berperan dalam melakukan perhitungan jarak dan waktu[7].

Dari penelitian sebelumnya didapatkan SAW dapat memecahkan masalah dalam mengambil keputusan, kontrol unit maupun peramalan. Oleh karena itu pada penelitian ini akan dilakukan pembangunan aplikasi "Sistem Pendukung Keputusan Penentuan Kualitas Benih Bunga Viola” untuk dapat memberikan alternatif terbaik benih bunga Viola yang akan diekspor.

Sistem Pendukung Keputusan (Decision Support System) merupakan sistem berbasis komputer yang diharapkan dapat membantu menyelesaikan masalah yang kompleks dan tidak terstruktur maupun yang semi terstruktur. Sistem penunjang keputusan merupakan perpaduan antara manusia dan komputer [8].

Multiple criteria decision making merupakan bagian dari masalah pengambilan keputusan yang relatif kompleks, yang mengikut sertakan satu atau beberapa orang pengambil keputusan, dengan sejumlah kriteria yang beragam yang harus dipertimbangkan, dan masing-masing kriteria memiliki nilai bobot, dengan tujuan untuk mendapatkan solusi optimal atas suatu permasalahan (Kusrini, 2009). Metode SAW Merupakan metode penjumlahan terbobot. Konsep dasar metode SAW adalah mencari penjumlahan terbobot dari ranting kinerja pada setiap alternatif pada semua kriteria (Kusumadewi, 2012). Metode SAW membutuhkan proses normalisasi matrik keputusan (X) ke suatu skala yang dapat diperbandingkan dengan semua ranting alternatif yang ada. Metode SAW mengenal adanya 2 atribut yaitu kriteria keuntungan (benefit) dan kriteria biaya (cost)[9]. 


\section{Metode Penelitian}

Penelitian dilakukan dengan menggunakan model proses waterfall yang merupakan model proses pembangunan perangkat lunak yang di mana fase proses harus diselesaikan satu demi satu untuk menuju ke fase proses selanjutnya. Adapun fase-fase proses dapat diulang tanpa adanya batasan hingga fase proses menjadi sempurna [10]. Adapun model proses waterfall dapat dilihat pada Gambar 1.

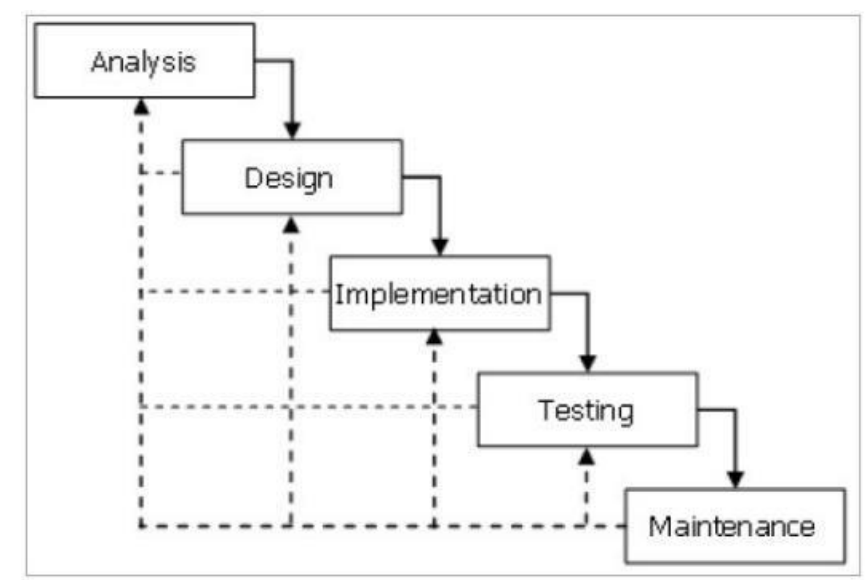

Gambar 1. Model Proses Waterfall [10]

\section{A. Analysis}

Pada tahap ini dilakukan pengumpulan informasi mengenai kebutuhan pengguna, yang dalam penelitian ini dilakukan wawancara dengan manager dan supervisor PT. Selektani dan melakukan observasi pada para pekerja untuk menemukan kendala ataupun masalah yang terjadi di lingkungan pekerjaan. Permasalahan yang didapatkan adalah sering terjadinya kesalahan dalam menentukan peringkat biji bunga Viola. Berdasarkan permasalahan yang didapatkan maka akan dibangun sebuah sistem pendukung keputusan penentuan kualitas benih bunga viola pada PT. Selektani untuk membantu menentukan peringkat biji bunga viola secara akurat dan membantu mengurangi risiko kehilangan data.

\section{B. Design}

Pada tahap ini dilakukan perancangan sistem pendukung keputusan yang akan dibangun berdasarkan informasi dan kebutuhan calon pengguna yang telah dilakukan pada tahap sebelumnya. Perancangan dilakukan dengan memindahkan hasil dari tahapan Analysis ke sebuah model bahasa yakni Unified Modeling Language (UML). Adapun perancangan model untuk pendukung keputusan menggunakan Fuzzy Multiple Attribute Decision Making (FADM) terlihat pada Gambar 3. Penerapan FADM dengan Metode SAW. Dalam Analisa ini, seluruh data diperoleh dari PT. Selektani akan diimplementasikan ke dalam model pendukung keputusan menggunakan FADM. Adapun langkah-langkahnya yaitu:

1) Menentukan Nilai Pembobotan Numeris, yaitu suatu nilai yang menunjukan ukuran dari suatu variabel, misalnya $10,35,40$, dan sebagainya [11].

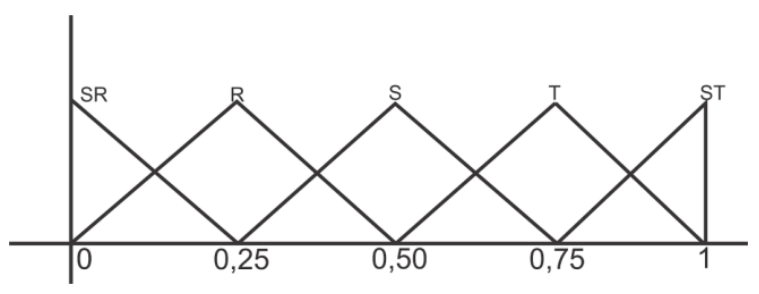

Gambar 2. Pembobotan Fuzzy 
Keterangan:

SR : Sangat Rendah

$\mathrm{R}$ : Rendah

$\mathrm{S} \quad$ : Sedang

$\mathrm{T}$ : Tinggi

ST : Sangat Tinggi

2) Menentukan rating kecocokan dan melakukan normalisasi dari setiap alternatif. Rumus yang dipakai terlihat pada Rumus (1).

$r_{i j} \begin{cases}\frac{X_{i j}}{\operatorname{Max}_{i j} X_{i j}} & \text { jika } j \text { adalah atribut keuntungan (benefit) } \\ \frac{\operatorname{Mini}_{i j} X_{i j}}{X_{i j}} & \text { jika } j \text { adalah atribut biaya (cost) }\end{cases}$

$$
\begin{array}{ll}
X_{i j} & =\text { Nilai Atribut yang dimiliki dari setiap alternatif } \\
\operatorname{Max}_{i j} & =\text { Nilai Terbesar } \\
\text { Mini }_{i j} & =\text { Nilai terkecil } \\
\text { benefit } & =\text { Jika nilai terbesar adalah terbaik } \\
\text { cost } & =\text { Jika nilai terkecil adalah terbaik }
\end{array}
$$

Setelah dilakukan normalisasi, kemudian memberikan nilai pada masing-masing kriteria sebagai berikut :

$$
\begin{aligned}
& \mathrm{W} 1=15 \%, \mathrm{~W} 2=15 \%, \mathrm{~W} 3=35 \%, \mathrm{~W} 4=35 \% \\
& \mathrm{~W}=[0.15,0,15,0,35,0,35]
\end{aligned}
$$

Selanjutnya hasil pemeringkatan atau nilai terbaik untuk setiap alternatif $\left(V_{t}\right)$ dapat dihitung dengan rumus sebagai berikut:

$$
V_{i=} \sum_{j=1}^{n} w_{j} r_{i j}
$$

Keterangan :

$V_{i}=$ Ranking untuk setiap alternatif

$W_{j}=$ Nilai bobot dari setiap kriteria

$r_{i j}=$ Nilai rating kinerja ternormalisasi

Nilai $V_{i}$ yang lebih besar mengindikasikan bahwa alternatif $A_{i}$ lebih terpilih.

Adapun aplikasi juga memberikan keterangan kualitas bunga berdasarkan pada poin yang didapatkan dari perhitungan SAW sebagai berikut: 1) Kualitas Baik untuk poin lebih dari 1;2) Kualitas Cukup untuk poin 0.75-1; 3) Kualitas Kurang untuk poin kurang dari 0.75. Proses penanganan masukan parameter dari pengguna menggunakan FADM metode SAW terlihat pada Gambar 3. 


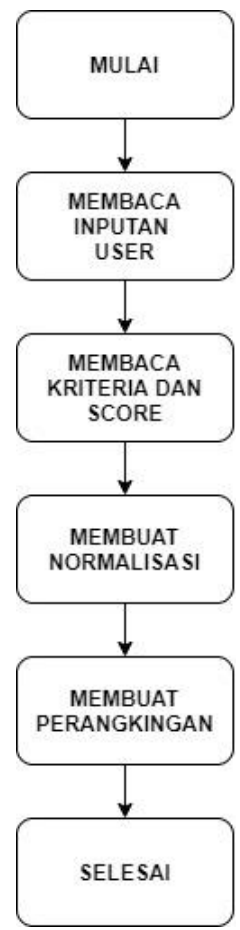

\section{Gambar 3. Alur Proses Data}

Proses pertama kali yang dilakukan sistem adalah membaca masukan pengguna apakah sesuai dengan yang sudah ditetapkan oleh sistem, langkah selanjutnya adalah sistem membaca kriteria dan mengambil data sesuai dengan kriteria masing-masing kemudian pada setiap kriteria memiliki bobot yang berbeda pada setiap kriteria. Setelah mengambil dan membaca setiap nilai kemudian sistem akan membuat normalisasi bentuk pertama dan dilanjutkan dengan normalisasi bentuk kedua. Setelah terbentuk normalisasi maka langkah selanjutnya dilakukan pemeringkatan atau memberikan peringkat dan proses pun selesai.

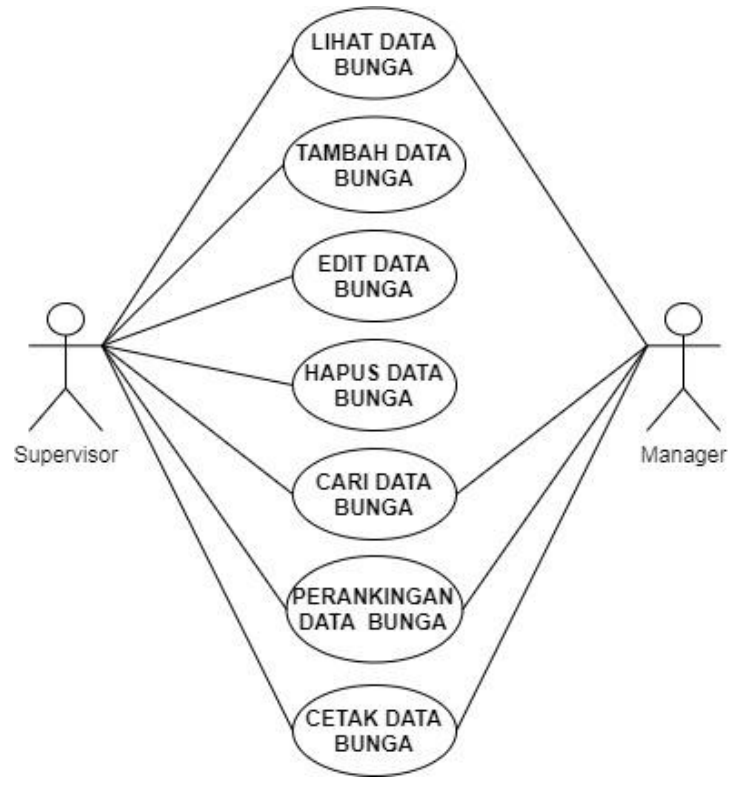

Gambar 4. Use case Diagram

Use case diagram adalah sebuah pemodelan yang berguna untuk menggambarkan sebuah sistem yang akan dibuat dengan mendeskripsikan tentang interaksi antara aktor dengan sistem. [12]. 
Sistem yang akan dibangun ini memiliki dua buah aktor yaitu Supervisor dan Manager. Supervisor memiliki hak untuk mengelola data-data tanaman yang dari mulai input (tambah) data, edit (ubah) data, hapus data cari data hingga mencetak sebuah laporan atau bisa dikatakan supervisor adalah pengguna dalam hal ini. Sedangkan untuk Manager memiliki hak lihat data, cari data dan cetak laporan saja. Selain use case diagram, dirancanglah proses alur aktivitas pengguna dalam sistem menggunakan activity diagram. Activity diagram tambah data bunga, hapus data bunga dan cetak data bunga terlihat pada Gambar 5.

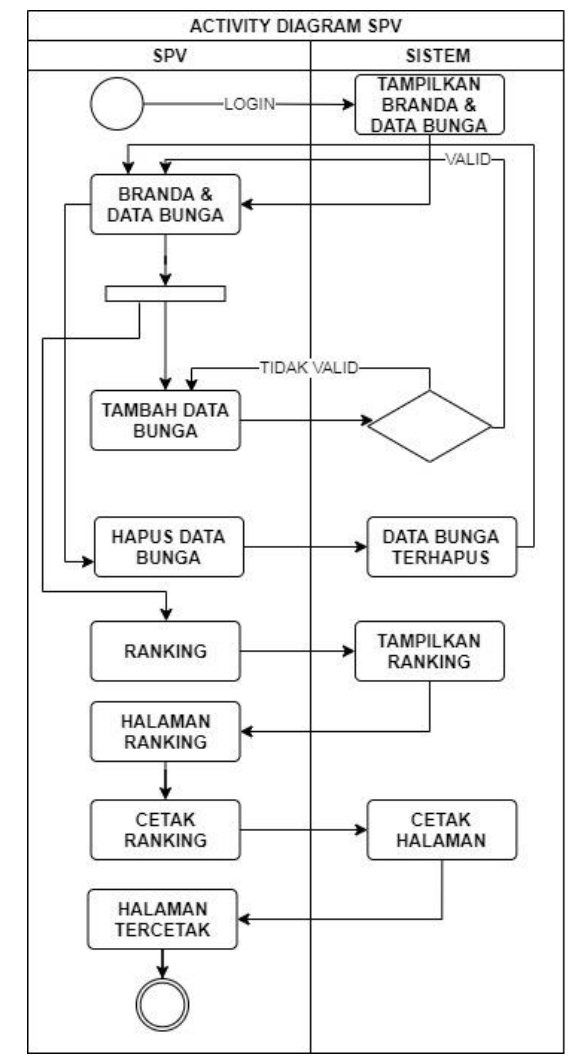

\section{Gambar 5. Beranda dan Tambah Data, Hapus Data, Cetak Ranking}

Dalam proses ini supervisor dapat melakukan penambahan data, sebelum melakukan tambah data supervisor dapat melakukan tambah data dengan kriteria-kriteria yang telah ditentukan. Apabila sudah mengisi form tambah dengan benar maka supervisor akan kembali pada menu beranda dan data yang telah dimasukkan akan terlihat. Jika supervisor melakukan kesalahan sistem akan memberikan peringatan pada kolom yang diisikan tidak sesuai. Pada $t a b$ menu hapus data, akan memunculkan $t a b$ menu baru berupa form hapus, ketika dipilih hapus data yang akan dihapus muncul dalam form tersebut, agar supervisor tidak salah/meminimalisir kesalahan. Supervisor akan melihat ranking bunga Viola melalui tab menu ranking. Tab menu ini dapat melakukan lihat hasil ranking yang dilakukan oleh sistem dan kemudian dapat mencetak/mengunduh pemeringkatan yang telah dilakukan menjadi file pdf.

\section{Implementation}

Pada tahap ini proses pengembangan sistem pendukung keputusan. Pada sisi back-end akan dibuat menggunakan bahasa pemrograman Hypertext Preprocessor (PHP) native dan pada sisi frontend akan dibuat menggunakan Bootstrap dan Javascript, pada sisi database yang akan dibangun menggunakan $M y S Q L$.

\section{Testing}

Pada tahap ini pengujian sistem pendukung keputusan akan dilakukan dengan menggunakan metode black box, pengujian persepsi pengguna dan evaluasi model. Pengujian black box difokuskan 
pada fungsional dari sistem pendukung keputusan. Kumpulan kondisi akan dimasukkan dan dilakukan pengetesan sesuai dengan spesifikasi yang telah dibangun. Pengujian kepada pengguna dilakukan untuk mendapatkan feedback apakah sistem sudah memenuhi fungsional yang diinginkan oleh pengguna. Sedangkan evaluasi model menggunakan confusion matrix untuk melihat akurasi dan presisi dari algoritma SAW yang digunakan.

\section{E. Maintenance}

Pada tahap ini perbaikan dilakukan apabila sistem memiliki kesalahan yang ditemukan dan memberikan tambahan-tambahan fitur bila diperlukan. Perbaikan dilakukan apabila sistem memiliki kesalahan yang ditemukan dan memberikan tambahan-tambahan fitur bila diperlukan.

\section{Hasil dan Pembahasan}

Hasil dari perancangan yang telah dilakukan digunakan sebagai dasar pembangunan Sistem Pendukung Keputusan Penentuan Kualitas Bibit Bunga Viola. Pembangunan SPK dilakukan menggunakan bahasa pemrograman Hypertext Preprocessor (PHP) dan framework Cascading Style Sheet (CSS) Bootstraps. Tampilan halaman utama atau landing page SPK terlihat pada Gambar 6.

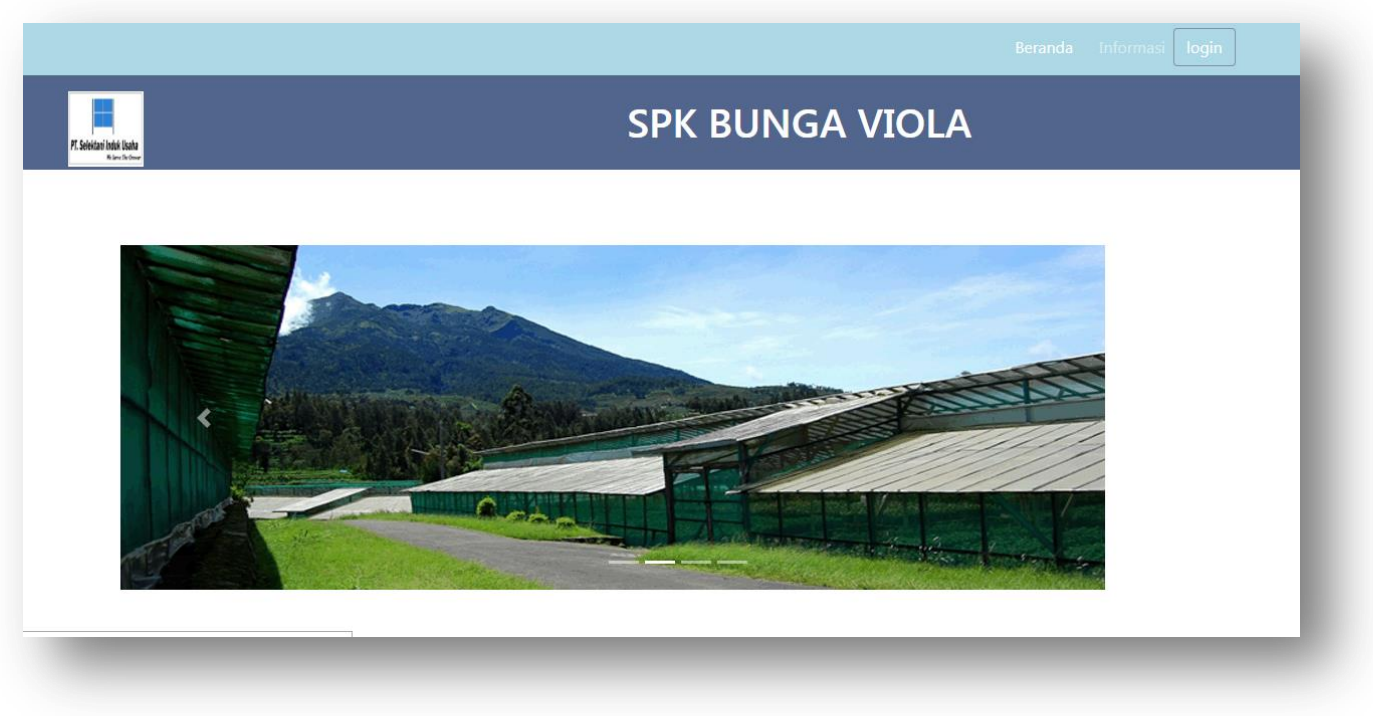

\section{Gambar 6. Homepage}

Gambar 6 adalah tampilan homepage saat pertama halaman sistem diakses. Pengguna dapat memilih ke halaman mana yang akan dituju. Tampilan ini dapat diakses oleh Manager atau Supervisor. 


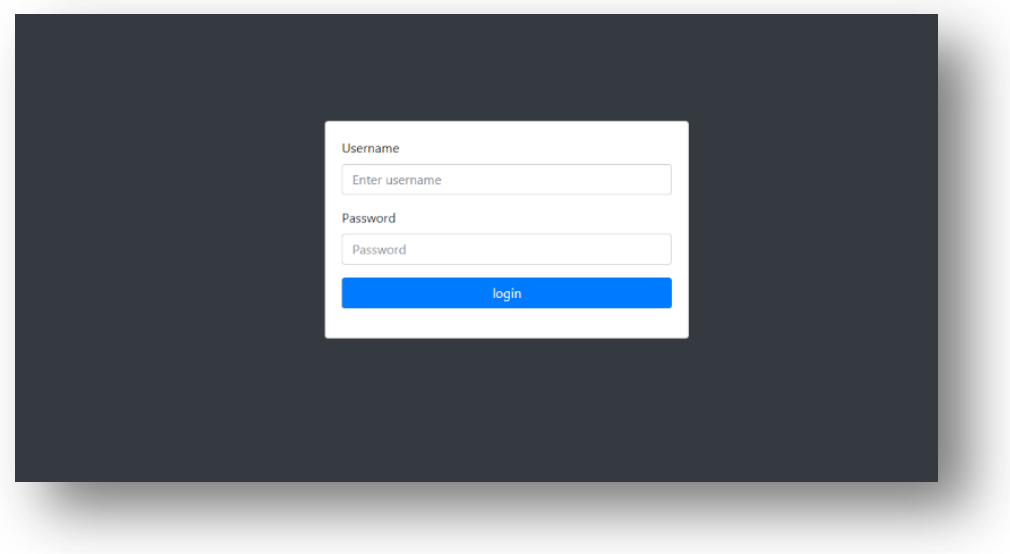

Gambar 7. Halaman Login

Pada Gambar 7 pengguna memasukkan username dan password, kemudian aplikasi akan memproses masukan dari pengguna dengan melakukan pencocokan dengan database. Apabila username dan password valid maka aplikasi akan menuju ke halaman dashboard, apabila username dan password salah maka sistem akan kembali menampilkan halaman login.

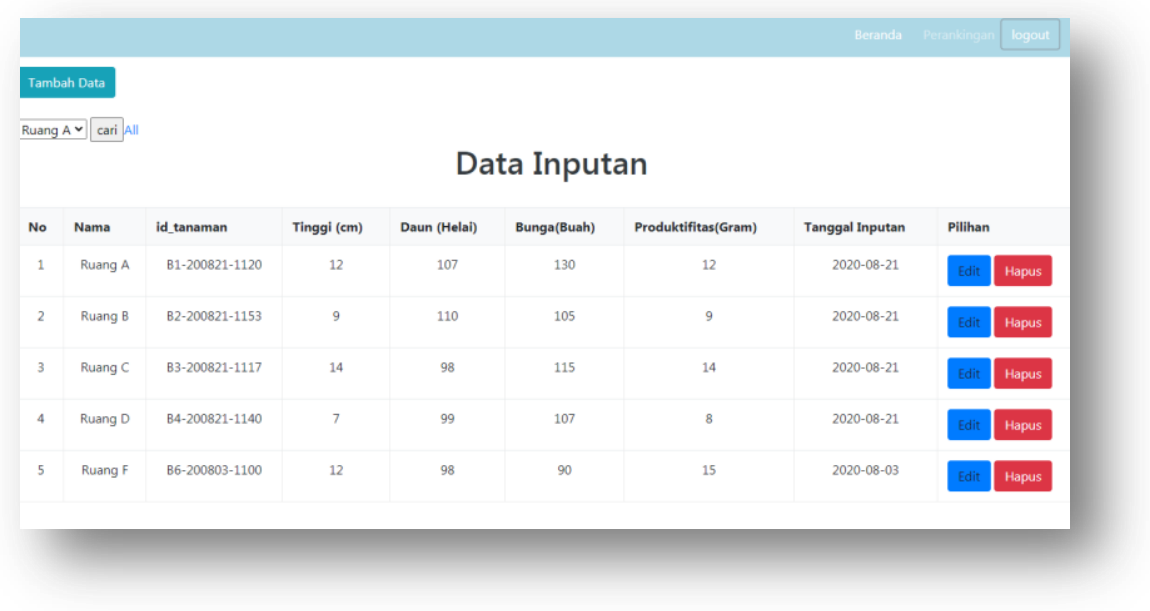

\section{Gambar 8. Daftar Data Bunga Viola}

Pada Gambar 8 pada halaman utama yang berisi informasi data tanaman yamg telah dimasukan berupa id tanaman, tinggi tanaman, jumlah daun, bunga, produktivitas dan tanggal tanaman yang telah dimasukkan ke dalam database. Pada halaman ini supervisor dapat menambah data bunga, mencari atau filter data berdasarkan nama ruang, dan mengubah data ataupun menghapus data. 


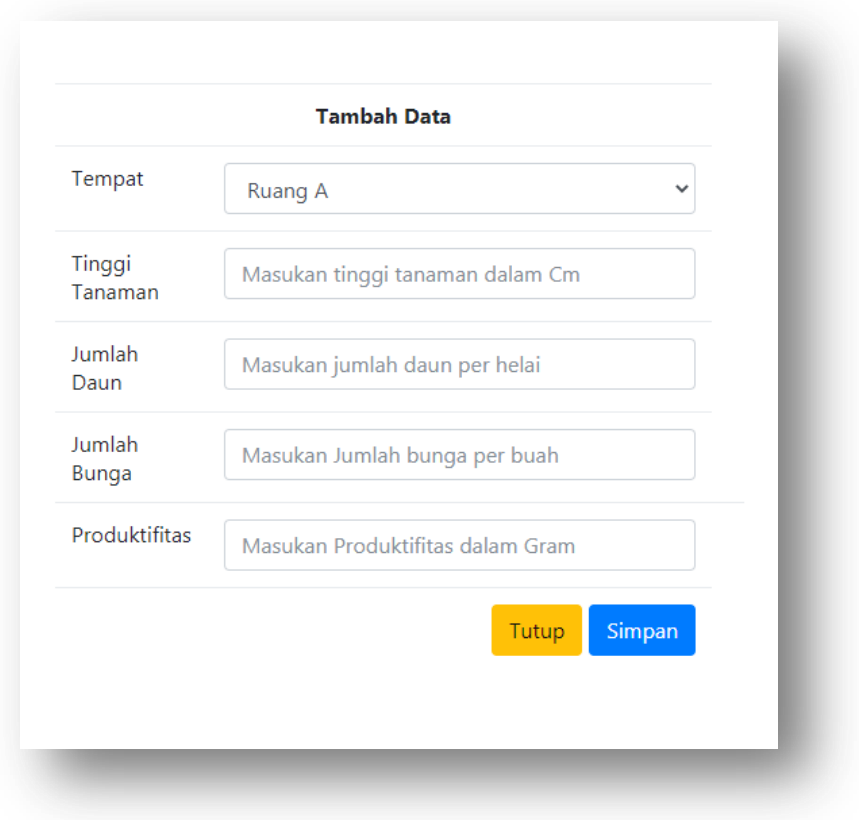

\section{Gambar 9. Tambah Data}

Pada halaman tambah data, pengguna dapat menambahkan data bunga berupa tempat ruangan bunga ditanam, tinggi tanaman, jumlah daun, jumlah bunga dan produktifitas yang berguna untuk perhitungan ranking benih bunga viola. Adapun halaman tambah data dapat dilihat pada Gambar 9 .

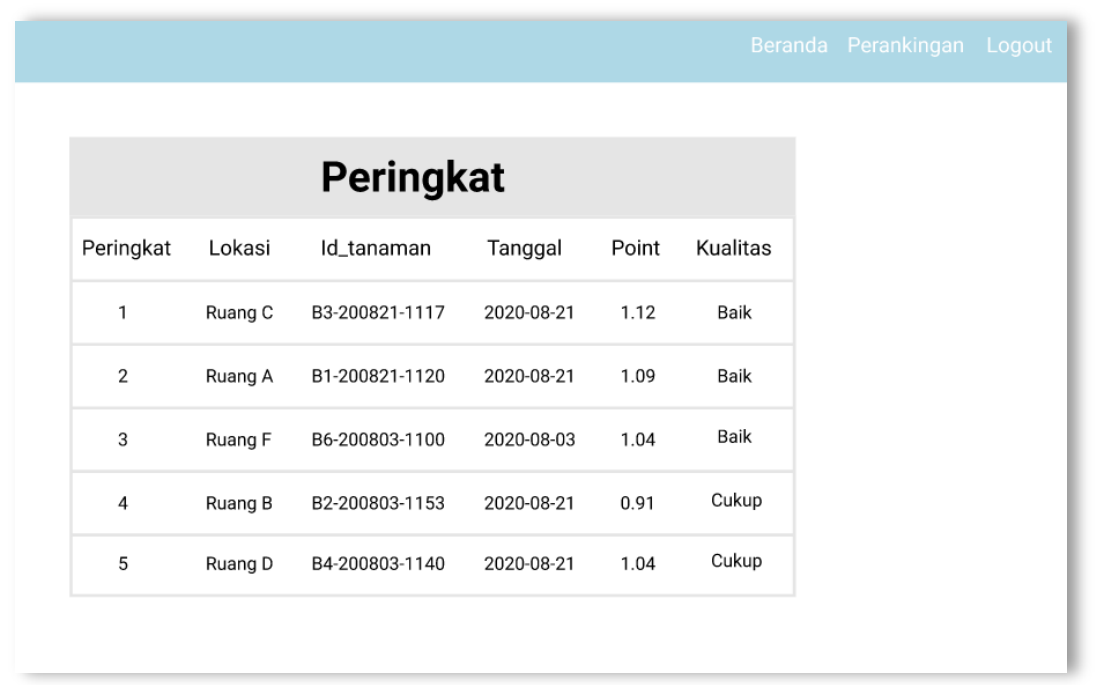

\section{Gambar 10. Pemeringkatan Benih}

Gambar 10 merupakan tampilan pada sistem yang menunjukkan peringkat bunga dari nilai terendah hingga nilai tertinggi serta kualitas dari biji bunga Viola yang telah dimasukkan. Akumulatif nilai diperoleh dari hitungan poin yang telah diproses untuk menghasilkan ranking. 


\section{Kode Program 1. Pencarian Nilai Max}

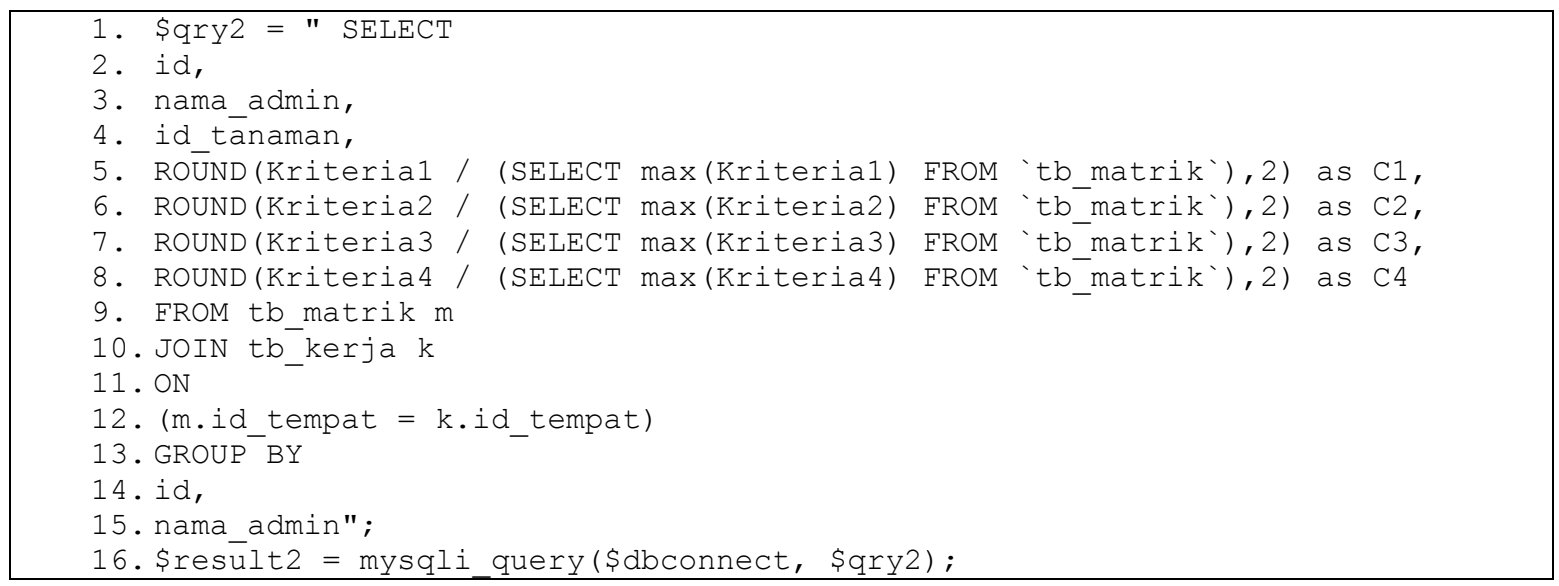

Pada Kode Program 1 masing-masing kriteria dicari nilai maksimal untuk menentukan normalisasi berdasarkan nama id dan nama_admin(nama ruang). Baris 1 hingga baris 4 kode program untuk memanggil id ruangan, nama_admin dan id_tanaman selanjutnya pada baris 5 hingga 8 dilakukan pencarian nilai maximalnya. Setelah dilakukan pencarian nilai maximalnya pada baris 13 hingga 15 dilakukan pengelompokan berdasarkan id dan nama admin.

\section{Kode Program 2. Perkalian Normalisasi dengan Bobot}

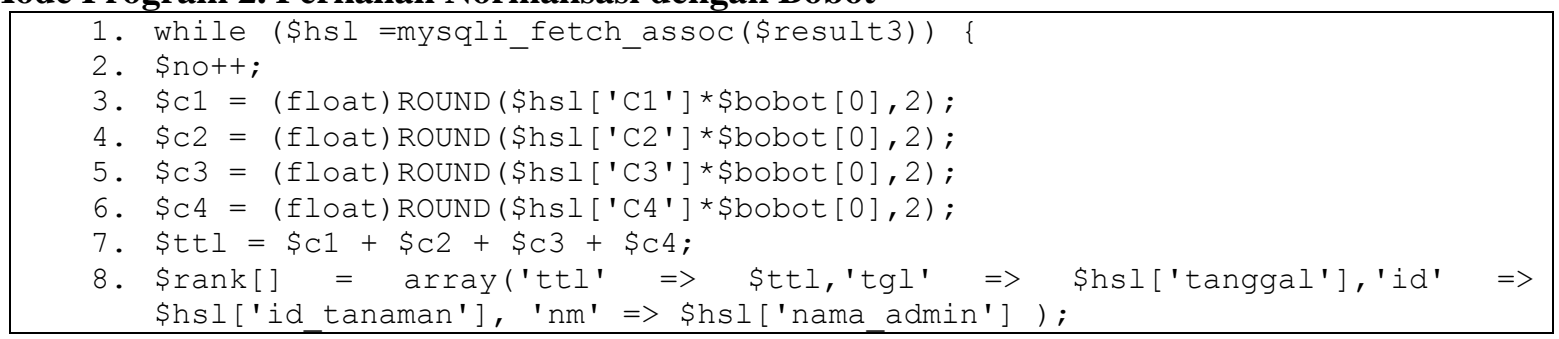

Pada Kode Program 2 masing-masing kriteria dikalikan dengan bobot yang telah ditetapkan oleh perusahaan dan pada proses ini akan mendapatkan nilai terbaik dari masing-masing ruangan yang berbeda. Baris 3 hingga 6 inputan pengguna yang berupa tinggi tanaman, jumlah bunga, jumlah daun dan produktifitas bunga dilakukan perkalian dengan bobot. Kemudian pada baris 7 setelah dilakukan perkalian semua kriteria ditambah untuk mendapatkan nilai.

\section{Kode Program 3. Pemeringkatan}

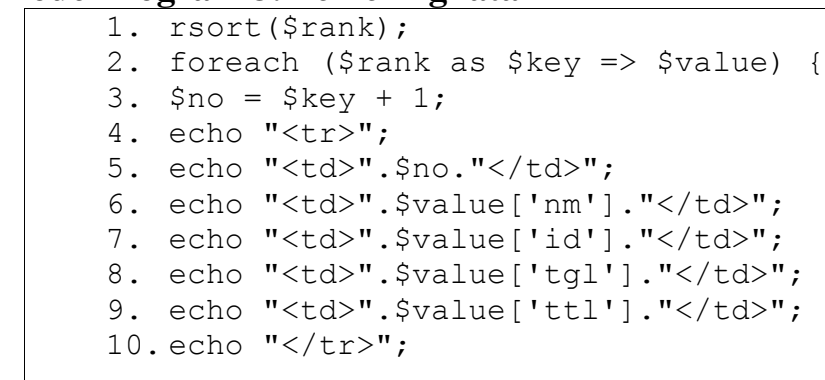

Pada Kode Program 3 dilakukan pemeringkatan data untuk menampilkan nilai terbaik dari data yang telah dilakukan dimana data yang memiliki nilai tertinggi akan berada urutan pertama dan ikuti nilai-nilai selanjutnya. 


\section{Pengujian Aplikasi}

Pengujian aplikasi dilakukan untuk mengetahui sistem dapat berjalan sesuai dengan yang diharapkan ataupun tidak sesuai yang diharapkan. Pengujian ini dilakukan dengan black box testing di mana pengujian ini dilakukan dengan menguji fungsionalitas sistem.

Tabel 1. Black Box Testing

\begin{tabular}{|c|c|c|c|}
\hline $\begin{array}{c}\text { Aktivitas dan } \\
\text { Event }\end{array}$ & Input & Output & Status Pengujian \\
\hline Pengguna login & $\begin{array}{l}\text { Username dan } \\
\text { Password }\end{array}$ & $\begin{array}{l}\text { a. Jika berhasil akan } \\
\text { menampilkan halaman dashboard } \\
\text { b. Jika gagal akan kembali pada } \\
\text { menu login }\end{array}$ & Valid \\
\hline $\begin{array}{l}\text { Pengguna } \\
\text { memasukkan data } \\
\text { bunga }\end{array}$ & $\begin{array}{l}\text { Ruangan } \\
\text { Tinggi Tanaman } \\
\text { Jumlah Daun } \\
\text { Jumlah Bunga } \\
\text { Produktifitas }\end{array}$ & $\begin{array}{l}\text { a. Jika berhasil akan menampilkan } \\
\text { data bunga } \\
\text { b. Jika gagal akan memunculkan } \\
\text { alert lengkapi data bunga }\end{array}$ & Valid \\
\hline $\begin{array}{l}\text { Pengguna Sorting } \\
\text { Data Bunga }\end{array}$ & Ruangan & $\begin{array}{l}\text { a. Jika berhasil akan menampilkan } \\
\text { data bunga pada salah satu ruangan } \\
\text { b. Jika gagal akan memunculkan } \\
\text { data bunga kosong }\end{array}$ & Valid \\
\hline $\begin{array}{l}\text { Pengguna Edit Data } \\
\text { Bunga }\end{array}$ & $\begin{array}{l}\text { Ruangan } \\
\text { Tinggi Tanaman } \\
\text { Jumlah Daun } \\
\text { Jumlah Bunga } \\
\text { Produktifitas }\end{array}$ & $\begin{array}{l}\text { a. Jika berhasil akan menampilkan } \\
\text { data bunga terbaru } \\
\text { b. Jika gagal akan memunculkan } \\
\text { kembali menu edit }\end{array}$ & Valid \\
\hline $\begin{array}{l}\text { Pengguna Hapus } \\
\text { Data }\end{array}$ & $\begin{array}{l}\text { Ruangan } \\
\text { Tinggi Tanaman } \\
\text { Jumlah Daun } \\
\text { Jumlah Bunga } \\
\text { Produktifitas }\end{array}$ & $\begin{array}{l}\text { a. Jika berhasil data bunga yang } \\
\text { dipilih akan terhapus } \\
\text { b. Jika gagal data bunga tidak } \\
\text { terhapus }\end{array}$ & Valid \\
\hline $\begin{array}{l}\text { Penguna Cetak } \\
\text { Ranking Data Bunga }\end{array}$ & $\begin{array}{l}\text { Ruangan } \\
\text { Tinggi Tanaman } \\
\text { Jumlah Daun } \\
\text { Jumlah Bunga } \\
\text { Produktifitas }\end{array}$ & $\begin{array}{l}\text { a. Jika berhasil data Ranking bunga } \\
\text { disimpan dalam bentuk pdf } \\
\text { b. Jika gagal data Ranking bunga } \\
\text { tidak dapat disimpan }\end{array}$ & Valid \\
\hline
\end{tabular}


Tabel 2. Daftar Pertanyaan dan Hasil Kuesioner

\begin{tabular}{|c|c|c|c|c|c|c|c|}
\hline \multirow[t]{2}{*}{ No } & \multirow[t]{2}{*}{ Pernyataan } & \multicolumn{5}{|c|}{ Jawaban } & \multirow[t]{2}{*}{ Persentase } \\
\hline & & $\begin{array}{c}\text { Sangat } \\
\text { Setuju } \\
(5)\end{array}$ & $\begin{array}{l}\text { Setuju } \\
(\mathbf{4})\end{array}$ & $\begin{array}{c}\text { Cukup } \\
\text { Setuju } \\
(3)\end{array}$ & $\begin{array}{c}\text { Tidak } \\
\text { Setuju } \\
\text { (2) }\end{array}$ & $\begin{array}{c}\text { Sangat } \\
\text { Tidak } \\
\text { Setuju } \\
(1)\end{array}$ & \\
\hline 1 & $\begin{array}{l}\text { Tampilan dan alur pengalaman } \\
\text { pengguna pada SPK mudah } \\
\text { dipahami }\end{array}$ & 2 & 2 & 1 & & & $84 \%$ \\
\hline 2 & $\begin{array}{l}\text { Menu yang ada cukup mudah } \\
\text { dipahami }\end{array}$ & & 3 & 2 & & & $72 \%$ \\
\hline 3 & $\begin{array}{l}\text { SPK dapat memberikan luaran } \\
\text { ranking bunga Viola yang tepat }\end{array}$ & & 3 & 2 & & & $72 \%$ \\
\hline 4 & $\begin{array}{l}\text { SPK dapat membantu } \\
\text { memberikan rekomendasi } \\
\text { kualitas bunga Viola }\end{array}$ & & 3 & 2 & & & $72 \%$ \\
\hline 5 & $\begin{array}{l}\text { SPK secara keseluruhan } \\
\text { membantu perusahaan dalam } \\
\text { pengersipan data bunga dan } \\
\text { penentuan kualitas bunga }\end{array}$ & 2 & 1 & 2 & & & $80 \%$ \\
\hline
\end{tabular}

Berdasarkan jawaban kuesioner yang diberikan kepada lima pegawai di PT. Selektani, diperoleh hasil perhitungan dengan menggunakan Skala Likert. Skala Likert adalah skala yang mempunyai empat atau lebih butir-butir pertanyaan yang digabungkan sehingga membentuk sebuah skor atau nilai yang mempresentasikan sifat individu [13]. Adapun hasil perhitungan yang didapatkan dari Rumus (3).

$$
f=\frac{a}{\text { Total Nilai }} \times 100 \% \text { Perhitungan Nilai Presentasi }
$$

Pada rumus (3), $f$ adalah nilai yang dicari presentasinya, $\alpha$ adalah nilai tertinggi Likert yang dikalikan responden, Total Nilai adalah jumlah dari masing-masing skala. Adapun hasil dari perhitungan skala Likert, dilakukan interpretasi skor berdasarkan nilai presentase yang dicari, dengan range yang terlihat pada Tabel 3 .

\begin{tabular}{|c|c|}
\hline Skor Kepuasan & Keterangan \\
\hline $0 \%-19,99 \%$ & Sangat Tidak Setuju \\
\hline $20 \%-39,9 \%$ & Tidak Setuju \\
\hline $40 \%-59,9 \%$ & Cukup Setuju \\
\hline $60 \%-79,9 \%$ & Setuju \\
\hline $80 \%-100 \%$ & Sangat Setuju \\
\hline
\end{tabular}

Berdasarkan Tabel 3 interpretasi nilai untuk masing-masing jawaban, dimana pengguna sangat setuju (84\%) tampilan dan alur pengalaman pengguna pada SPK mudah dipahami. Pengguna juga setuju menu yang ada cukup mudah dipahami (72\%). Pengguna menilai setuju bahwa SPK dapat memberikan luaran ranking benih bunga Viola yang tepat (72\%). Pengguna setuju SPK dapat membantu memberikan rekomendasi kualitas benih bunga Viola (72\%). Pengguna setuju SPK secara 
keseluruhan membantu perusahaan dalam pengarsipan data bunga dan penentuan kualitas benih bunga sudah cukup baik untuk digunakan(80\%).

Selain itu juga dilakukan pengujian akurasi terhadap pengimplementasian SAW pada penentuan kualitas benih bunga Viola menggunakan confusion matrix yang merupakan metode pengujian yang digunakan untuk perhitungan akurasi, recall, precision dan error rate [14], [15]. Hasil confusion matrix terlihat pada Tabel 4.

Tabel 4. Confusion Matrix

\begin{tabular}{|c|c|c|c|}
\hline \multirow{2}{*}{$\begin{array}{l}\text { Kelas } \\
\text { Aktual }\end{array}$} & \multicolumn{3}{|c|}{ Kelas Prediksi } \\
\hline & Baik & Cukup & Kurang \\
\hline Baik & 58 & 7 & 3 \\
\hline Cukup & 3 & 32 & 1 \\
\hline Kurang & 2 & 4 & 10 \\
\hline Total & 63 & 43 & 14 \\
\hline Presisi & $92,1 \%$ & $74,42 \%$ & $71,43 \%$ \\
\hline
\end{tabular}

Dari Tabel 4 tersebut maka dapat dihitung akurasi implementasi SAW pada penentuan kualitas benih bunga Viola dengan rumus 4 [16], [17].

True Positive+True Negative

$$
\text { Total }
$$

Sehingga didapatkan:

$\frac{58+32+10}{120} \times 100 \%=83,34 \%$

\section{Kesimpulan}

Penelitian ini menghasilkan sistem pendukung keputusan yang mampu memberikan ranking dari kualitas bunga Viola. Berdasarkan hasil penelitian yang telah dibahas dan pengujian pada SPK yang telah dilakukan, didapatkan bahwa penerapan SAW mampu memberikan ranking serta kelompok kualitas benih bunga Viola berdasarkan kriteria yang ada yaitu tinggi tanaman, jumlah daun, jumlah bunga dan produktifitas. Adapun akurasi penerapan SAW pada penentuan kualitas benih bunga Viola sebesar 83,34\%. Dari pengujian yang dilakukan kepada pengguna didapatkan bahwa SPK yang dibangun membantu perusahaan dalam menentukan kualitas benih bunga Viola serta membantu pengarsipan data-data bunga Viola.

\section{Referensi}

[1] S. Singh, S. Ahlawatat, and S. Sanwal, "Role of ICT in Agriculture: Policy implications," Orient. J. Comput. Sci. Technol., vol. 10, no. 3, pp. 691-697, 2017, doi: 10.13005/ojcst/10.03.20.

[2] I. Javeed et al., "The role of information and communication technology in agriculture," Int. J. Curr. Microbiol. Appl. Sci., no. March, pp. 3528-3531, 2020, doi: 10.1109/ICISE.2009.1282.

[3] N. Pandey, "Role of Information and Communication Technology in Agriculture Development: a Study of Nabarangpur District," Sch. Int. J. Bus. Policy Gov. ISSN 2394-3351, vol. 4, no. 4, p. 24, 2017, doi: 10.19085/journal.sijbpg040401.

[4] S. Kusumadewi, Fuzzy multi-attribute decision making (fuzzy madm). Yogyakarta: Graha Ilmu, 2006.

[5] A. Rikki, M. Marbun, J. R. Siregar, and K. Kunci, "SISTEM PENDUKUNG KEPUTUSAN PENERIMAAN KARYAWAN DENGAN METODE SAW PADA PT . KARYA SAHATA MEDAN," vol. 1, no. 1, 2016.

[6] R. Taufiq and A. A. Permana, "Sistem Pendukung Keputusan Penerimaan Karyawan Menggunakan Simple Additive Weighting Studi Kasus PT. Trafoindo Prima Perkasa," J. Al- 
AZHAR Indones. SERI SAINS DAN Teknol., vol. 4, no. 4, p. 186, 2018, doi: $10.36722 /$ sst.v4i4.309.

[7] V. N. Firdausy, F. Agus, and I. F. Astuti, "Aplikasi Android Hybrid Untuk Pemilihan Lokasi Kuliner," Inform. Mulawarman J. Ilm. Ilmu Komput., vol. 12, no. 1, p. 30, 2017, doi: 10.30872/jim.v12i1.220.

[8] M. Hendrawan, "Rekrutmen Karyawan Di Pt Indo Beras Unggul Menggunakan Metode Analytical Hierarchy Process ( Ahp )," J. Ilm. Komput. dan Inform., 2014.

[9] M. Elistri, J. Wahyudi, and R. Supardi, "Penerapan Metode SAW Dalam Sistem Pendukung Keputusan Pemilihan Jurusan Pada Sekolah Menengah Atas Negeri 8 Seluma," J. Media Infotama Penerapan Metod. SAW... ISSN, vol. 10, no. 2, pp. 1858-2680, 2014.

[10] Y. Bassil, "A Simulation Model for the Waterfall Software Development Life Cycle," vol. 2, no. 5, 2012.

[11] E. Tajvidi Asr, M. Hayaty, R. Rafiee, M. Ataie, and S. E. Jalali, "Selection of Optimum Tunnel Support System Using Aggregated Ranking of SAW, TOPSIS and LA Methods," Int. J. Appl. Oper. Res., vol. 5, no. 4, pp. 49-63, 2015.

[12] D. S. Anwar and D. Rohpandi, "Sistem Pendukung Keputusan Untuk Menentukan Lahan Tanaman Cabai Dengan Menggunakan Metode Simple Additive Weighting." pp. 657-660, 2018.

[13] N. Setiyawati and M. Hariyanto, "Rancang Bangun Aplikasi Perizinan Surat Tugas dan," vol. 5, no. April, pp. 213-220, 2020.

[14] T. Rosandy, "PERBANDINGAN METODE NAIVE BAYES CLASSIFIER DENGAN METODE DECISION TREE (C4.5) UNTUK MENGANALISA KELANCARAN PEMBIAYAAN (Study Kasus: KSPPS / BMT AL-FADHILA,” J. Teknol. Inf. Magister Darmajaya, vol. 2, no. 01, pp. 52-62, 2016.

[15] N. W. A. Ulandari, G. R. Dantes, and D. G. H. Divayana, "Implementasi Metode AHP dan SAW dalam Sistem Pendukung Keputusan Prediksi Potensi Akademik Mahasiswa STMIK STIKOM Bali," J. Pendidik. Tek. Inform., vol. 9, no. 1, pp. 223-227, 2018.

[16] D. Nasution, H. H. Khotimah, and N. C. Chamidah, "PERBANDINGAN NORMALISASI DATA UNTUK KLASIFIKASI WINE MENGGUNAKAN ALGORITMA K-NN," vol. 4, no. 1, pp. 78-82, 2019.

[17] A.- Arini, L. K. Wardhani, and D.- Octaviano, "Perbandingan Seleksi Fitur Term Frequency \& Tri-Gram Character Menggunakan Algoritma Naïve Bayes Classifier (Nbc) Pada Tweet Hashtag \#2019gantipresiden," Kilat, vol. 9, no. 1, pp. 103-114, 2020, doi: 10.33322/kilat.v9i1.878. 